\title{
Christoph Türcke's Studies on the Origins of Money in Sacrifice
}

\author{
Alberto da Silva Moreira \\ Sciences of Religion Graduate Studies Program, Pontifical Catholic University of Goiás, Goiania, Brazil \\ Email: alberto-moreira@uol.com.br
}

How to cite this paper: da Silva Moreira, A. (2021). Christoph Türcke's Studies on the Origins of Money in Sacrifice. Open Journal of Social Sciences, 9, 161-172. https://doi.org/10.4236/jss.2021.94013

Received: March 16, 2021

Accepted: April 17, 2021

Published: April 20, 2021

Copyright (C) 2021 by author(s) and Scientific Research Publishing Inc. This work is licensed under the Creative Commons Attribution International License (CC BY 4.0).

http://creativecommons.org/licenses/by/4.0/

\begin{abstract}
This paper examines the contribution of the German philosopher Christoph Türcke to the understanding of the origins of money, which according to his paleo-historical and phylogenetic reconstruction are to be found in sacrifice, the oldest form of religion. The study is part of a broader, mostly bibliographical research about capitalism as religion, which purpose is to analyze capitalism as everyday life religion. Türcke approached the Critical Theory and Freud's psychoanalysis, adding to these, a theory of traumatic compulsion to repetition as a creative force in culture and Civilization. In his work "Mehr! Philosophie des Geldes" (More! Philosophy of Money), referred to Simmel's homonymous book, Türcke traces back the origins of money and currency to the mechanism of ritual sacrifice. According to him, sacrifice is based on the payment of a debt or guilt that is exchanged for an offering of equivalent value, the victim. In the sacrifice ritual and its compulsive repetition, Türcke locates both the starting point of Homo sapiens mentalization process and the beginning of payment in human history. Since then and despite of all the changes he underwent money never lost its deep rootedness in the sacred sphere.
\end{abstract}

\section{Keywords}

Money, Sacrifice, Capitalism, Religion, Christoph Türcke

\section{Introduction-The Author and His Work}

Christoph Türcke was born in 1948 in Hameln, Lower Saxony, where he went to school until high school. During his theological studies in Göttingen, Tübingen and Zürich, Christoph Türcke assumed a critical position about Religion, approaching the Critical Theory and the Psychoanalysis of Freud. Türcke added to these two currents of thought a Theory of Compulsion to Traumatic Repetition 
as a creative force of culture, and as one of the leading factors in the historical formation of the Western Civilization. Türcke finds in the logic of compulsive repetition the starting point of the Homo sapiens mentalization process and also the beginning of the writing and payment techniques. This issue will be better developed ahead. When making the diagnosis of the current society and culture, Türcke stated that instead of progress and innovation, we are mentally returning to the archaic and Neolithic mind under the conditions of high technology. In 1994, Türcke published in the German newspaper Die Zeit nine articles about changes in culture and religion, dealing mostly about the permanence of religious concepts (such as blasphemy, martyrdom, grace) in the profane language of everyday life. In 2003, with the attacks on the World Trade Center as a backdrop, he published the book Fundamentalismus: Maskierter Nihilismus (Fundamentalism-Masked Nihilism) (Türcke, 2003), where he interprets fundamentalism and fanaticism as disguised forms of atheism. His main work of social analysis is Erregte Gesellschaft. Philosophie der Sensation (Excited Society-Philosophy of Sensation, 2002), in which he interpreted the (post) modern obsession for strong sensations and emotions (sensation seeking culture) as an encrypted and ongoing form of the religious hierophanies of the past. ${ }^{1}$

For Türcke, through the obsession for the sensational and the increasing dependency of sensations in modern culture, humans are re-archaizing the whole mental process, returning to the Neolithic in their structure of perception and in their drives. In 2008, Türcke wrote the book Philosophie des Traums (Philosophy of Dreams, English edition of 2013, Brazilian ed. 2010, Türcke, 2008) in which, in constant debate with Freud, he developed a cognitive-drive genealogy of thought and language. The latent trends of re-archaization in the high-tech society led him to publish two studies on hyperactivity, attention deficit disorder, learning and schooling: Hyperaktiv! Kritik der Aufmerksamkeitsdefizitkultur (Hyperactive! Criticism of the attention deficit culture, Türcke, 2012) and Lehrerdämmerung. Was die neue Lernkultur in den Schulen anrichtet (Teachers twilight. What the new learning culture is doing in schools, Türcke, 2016). In these books, Türcke analyzed how the new teaching and learning culture take away schools and teachers from their previous social and intellectual role. For the author, the new culture of learning globally required by neoliberalism is a vital threat to the ability of people to concentrate, to think autonomously, and to endure. In 2019, summarizing and deepening the line of research on the re-archaization of modern man, Türcke wrote Digitale Gefolgschaft. Auf dem Weg in eine neue Stammesgesellschaft (Digital Allegiance: Towards a New Tribal Society, Türcke, 2019). In this book the author analyzes the digital world as an impenetrable forest, with a few paths dominated by the great digital platforms such as Google, Facebook, Whatsapp, or Twitter. These platforms assume the role of large clans, within which, because of the enormous social pressure, herds of

${ }^{1}$ In other papers I tried to make useful the Türcke's concept of "sensation seeking society" to understand the ongoing process of aestheticization of social life, especially the aestheticization of religion (Moreira, 2015, 2019). 
compulsory members, the followers, come inescapably together. Whoever does not join the herd has no chance, is out of culture and society. The loss of autonomy, the dependence and the fixation to which we are submitted are for Türcke clear elements of a complete form of retribalization of the society.

In this article, I present and discuss the book Mehr! Philosophie des Geldes (More! Philosophy of Money, Türcke, 2015), in which Türcke retraced the social process of establishing money as a value and replacement means from the Stone Age to the modern financial market. He sees money fundamentally as a means of payment and atonement for a debt or guilt, as a SchuldtilgungsmitteP, which began in the sacred rituals of sacrifice. Türcke defends the thesis that until today the fascination caused by money has never escaped its roots in the context of the primitive sacred. In the following, I present only the main insights and arguments of the author, highlighting the original contributions he brought to the issue of capitalism as religion. The titles of Sections 2, 3 and 4 follow at large the book contents sequence. At the end, I make some comments and draw some conclusions.

Türcke's studies on the origins of money in sacrifice are important not only for their historical character and their roots in the sacred and the collective unconscious, but also because they dialogue with texts by other thinkers, such as Walter Benjamin (1985), Dirk Baecker (2009), Michel Löwy (2006), Franz Hinkelammert (2008), Hugo Assmann and other thinkers of Liberation Theology, who also reflected on the sacredness of money and the idolatry of capital in modern capitalist societies.

\section{Sacrifice-Atonement and Payment of Guilt-Debt}

Even more than Walter Benjamin, Hugo Assman, or Franz Hinkelammert (and also in a different way from these authors), Christoph Türcke does not identify capitalism only as a late historical form of practical and profane religion that would have appeared over the rubble of religion or traditional Christianity. He locates in the very enabling condition of the capitalist system, in money itself, as a universal equivalent, a nature, or a function, which has never ceased to be linked to the structure of a primeval and archaic sacred. Contemporary capitalism is, for Türcke, the current form of substitution and symbolic-sacred payment, that emerged at the dawn of the humanization process, continuously reproduce an archaic and unconscious dependence on the sacred with its operating mechanism.

The basic questions that the author asks himself at the beginning are: What is it? Where does it come from? How does money work? Money does not exist by itself, nor belongs to nature as water, trees and air. It needs human beings and social relations to be money. Why did money become the universal value meter of our times? Money, as Marx had already analyzed, has a mysterious nature: despite being only quantity, after a certain level, it also measures the qualitative.

${ }^{2}$ Schuldtilgungsmittel: in German the word Schuld means guilt as well as debt; tilgen = atone/pay; middle to pay or atone debt/guilt. 
In money, many human issues are most of the time hidden and do not appear. However, in times of crisis and crash it is very clear that money pervades human life and emotions. For example, during recent financial crashes, people got depressed or committed suicide because of money.

According to Türcke, Georg Simmel (Simmel, 2008) in his Philosophie des Geldes (1900) - from which Türcke took inspiration and the title for his own work-dealt with the emotional and aesthetic aspects of money, but did not explain what value is. In order to demonstrate this, Türcke performs a genealogy of money in the Western Civilization. But he does not stop at the explanations of Marx, Smith, Hegel, or even Aristotle, which he considers simplistic, according to which money-first in the form of currency-would have arisen or been created to facilitate the exchange of goods. This is what Marx, following Adam Smith, initially calls a more or less arbitrary choice of a specific commodity to operate as an equivalent of all the others and thus to facilitate the exchange of unequal things for an equivalent that equals and replaces everything. According to this explanation, the choice of the equivalent would have historically fallen on a special type of commodity, the precious metals: silver, bronze, and gold. Due to their favorable physical properties, metals would be minted in the form of coins and would function as money, the universal equivalent. For Türcke, this traditional explanation does not satisfy. For him, money and interest can only be understood within a paradigm of debt (and guilt), never through a paradigm of exchange, even though the need to make exchanges was real and cannot be ignored. When looking phylogenetically at the root of ancient words for money in the Indo-Germanic languages, Türcke believes he can find evidence for his claim: money must have arisen in an elementary context of debt and payment, interest and credit.

Nevertheless, to answer the question "where and when did money come from?" it is not enough to study the economy until the first great civilizations and their market forms. Türcke thinks that money was not born in the markets of the Ancient World, presenting much older roots. In fact, temples and priests financed caravans and exported grain and imported other goods in ancient $\mathrm{Ba}$ bylon before the kings did. The earliest records report that the money revolved around temples and priests. The oldest form of value measurement recorded in the West is the ox, the tame cattle. Homer (late $8^{\text {th }}$ century BC) reports that a woman is worth four oxen, a healthy slave up to eight cattle heads. At that time, the ox was already a normal equivalent of value. The ox was the most valuable thing that the oldest and still precarious farming peoples had. Since it was the most valuable thing, it was precisely the animal used in the sacrifices. The ox was valuable and became equivalent to other commodities because it was the animal to be sacrificed. Türcke analyzes how in ancient Greek accounts, as in the funeral reported by Procollus, in the victory against Troy, and on other solemn and special occasions, oxen were sacrificed in great numbers. This has been recorded in the language until today: the word hecatombe, for example, means the sacri- 
fice of a hundred oxen. However, Türcke goes even further, into prehistory, for analyzing a period up to some 100,000 years before the emergence of writing and the Great Civilizations. Money, due to the weight and meaning it has in life, including in the emotional life of human beings, must be much older, and have a long prehistory.

The sacrifice of the most valuable thing points to the known fact that before the ox there were human sacrifices. The initial and primitive sacrifice of human beings gradually underwent a process of substitution - which is also a process of desecration, of deceiving the divinity. However, why did mankind sacrifice itself? To answer this question, Türcke turns to Neurology and Paleoneurology, because from the mists of time surrounding the emergence of Homo sapiens, archaeological data, or historical records did not come to help understand the reasons and circumstances of offering sacrifices. What exists, according to Türcke, are neurological fragments, nervous tics, pulsations, language flaws, indications that point out to the complex process of formation of the human brain and of the mental ability of Homo sapiens itself.

In the absence of documents or archaeological remains, Türcke traces the genealogy of money in two levels: through the Freudian and beyond Freudian analysis of the unconscious and the philological study of the traces left in the language by the shocking and traumatic experiences. A recurring experience in humanity, especially after highly violent and traumatic events, such as wars, disasters and massacres, is the continuous reappearance of shock in the form of dreams. The brain repeats with shock the traumatic experience of dread, the dreadful fear of the sinister. Traumatic neurosis, or compulsive repetition (later in dreamlike or symbolic form) of dread and violent experiences, is the form of therapy that the human mind seems to use to try to heal itself from trauma. The brain tries to "provide to the unbearable overexcitation (overload) a possibility of discharge" (2010, p. 124). This need to find discharge and compensation for dread and trauma through repetition, was for Türcke a neuronal force that induced the formation and growth of the Homo sapiens brain. It has therefore become a key factor in the development of human culture itself. It creates memory, the memory of the dread to be exconjured.

Repetition domesticates dread, sublimates the monstrous, transforms it into anguish, into an entity, into something with unknown powers or a divinity with which humans can establish a relationship, such as feeling indebted. Therefore, it needs to be appeased, compensated, and satisfied. The collective catharsis takes place through sacrifice, which over the centuries has taken more and more ritual forms. At the beginning, however, only the violent and deaf fury that wants to kill and sacrifice other hominids that placate the angry nature or divinity. A blind and violent mob that needs to make up for a fault, pay a debt, atone for a guilt in relation to this unknown force or super powerful deity. The horde ritually unleashes its violence on the victim and thus appeases itself and restores the order of daily life. 
Nevertheless, according to psychoanalysis, the trauma of the monstrous is never completely gone. Instead, it is repressed from the conscious, always coming back as a repression, which must be atoned and expiated again. Here, Türcke finds the beginnings of religion and money, in the bloody sacrifice of men and animals. Again he finds numerous traces of this sacrificial origin in language: the Greek word rezein and the Latin word operari to "act", also mean "to sacrifice", "to offer" (cf. Burkert, W. (1997) apud Türcke, 2010: p. 139, note 18). According to Türcke, in the depths of humanity, as far as the few traces of this violence in the human unconscious indicate, there was a collective feeling of the need to appease the violent and destructive powers of nature. Homo sapiens feels lacking in these forces, feels that he must do something to calm down and satisfy these devastating and terrible powers. You feel in debt, you feel the need to make up for this lack, to pay this guilt. The way found was to offer the best of yourself, the sacrifice of other human beings. In the genealogy traced by Türcke, sacrifice appears as the most archaic and prehistoric form of religious practice, much older than any religion in the modern sense, which has probably been carried out over hundreds of thousands of years.

For Türcke, Homo sapiens only became specifically human through the desire to redeem or pay a guilt that is also a debt. The need to atone or pay a guilt/debt is for him a force, a powerful vector in human history. Debt or guilt rescue is experienced both individually and collectively as a form of catharsis, liberation, salvation. The victim of sacrifice then becomes the first form of payment in history. Someone is sacrificed so that others are spared; someone is sacrificed to pay their debt or default. The violence is such that it is only feasible if the whole community participates and validates it in a form of collective trance. The victim is the first reference of value; he/she becomes the first equivalent of value. The debt or guilt may be imaginary, but the payment is from the beginning very real. According to Türcke, the calculation mechanism itself was born in this context.

Guilt and thanks are mixed. Those who, through their death, pay the debt and the guilt of others, become valuable referents, become expensive, are at the beginning of the process of assigning value, practicing valuation, valuing things. The Greek word "time" means to give, to attribute value. The greatest value is sacrificed to divinity, although due to the growing collective guilt complex and sadness that sacrifices create in the community, a long process of substitution and desecration in the ritual of sacrifice started over the years. A form of deception of the deity is created, which Türcke calls priestly cunning. At some point in the Neolithic period, 14 or 12 thousand years ago, in the East, priests replaced and transferred the value of the human being to the ox. The ox becomes the real equivalent of collective or personal debt to the superpower deity. The original Indo-European word peku, pecus still records this equivalence cattle $=$ money, which is more evident in latin languages: catle or sheep (pécora) raising: pecuaria; monetary activity: pecunia, pecuniary.

The change of the victim from the human to the animal is seen as sacrilege, a 
lie against the divinity, but over time, the same replacement process happened in relation to the ram and other smaller animals. Finally, clay and ceramic objects are also offered, then incense, perfumes, and money itself, but the fundamental reason remains the same: payment or atonement for a debt or fault. From the beginning, the history of means of payment is a history of substitution and, therefore, of the desecration and deceit of the divinity. In other words, it is also always a story of emancipation from the divinity.

\section{The Temple, the Bank and the Deity's Capital}

According to Türcke, later on, after the bloody sacrifice phase, sculpted or modeled copies of the animals in gold, silver, and other metals were offered in the temple. In the beginning, they should have the weight or shape of the animal to be sacrificed. However, since metals are durable, instead of being offered in sacrifice, offerings were deposited for and in the name of the deity: they become the property of the deity to whom they were offered. The managers of these offers, of course, were the priests of divinity. The temple itself, which previously designated simply a circumscribed space, a sacred sand on which the sacrifice was performed, then becomes a building, a construction, and assumes this function of keeping the offerings destined to the deities. Babylonian temples accumulated enormous treasures and became large buildings, large deposits of cereals and offerings, around which villages were soon created. The priests started to fuse the metal figures offered to the gods again and resell them for a fee. Temples became the first banks, with immense treasures in Ancient Greece and in the (Middle) East. Here Türcke finds out the first impulse of capitalist accumulation, the insatiable hunger for more wealth. According to him, the accumulation started in the temples, on the sacred sphere, and then it was also assumed by kings and military leaders, migrating to the political sphere. Avarice and hunger for riches would have started in the temple, in the space of the sacred. In any case, the treasure of ancient temples became a coveted prey, the cause of wars, sieges, and military conquests in the whole Ancient World. Apart from that, in the East, the treasure of the temples funded caravans, the great international trade, the expansion projects of kings; becoming the first genuine form of big capital and always being reinvested again.

The priests, who at the beginning were involved with other occupations and jobs, became professional, being also entitled to a reward, a payment for their work. This started with a large portion of the meat of the sacrificed animals, which was consumed at ceremonial banquets. Later on, since the offers were made in the form of metal figures, this procedure changed, and the fees appeared. The first type of wage labor in history must have been that of the priest; and the first type of interest was paid to the temple, when it lent gold or metals to large merchants for an extra fee. Again, the language let it registered: Oikonomia: money, property, salary, payment, interest, bank, capital, all this already existed, according to Türcke at the same time that the treasure of the temple was 
formed, among the peoples between the Ganges and the Mediterranean.

\section{Money, Currency, Salary}

The currency, much later, appeared in the Greek polis, also in the context of sacrificial banquets. According to Türcke, priests and temple officials were paid in the form of participation in the meat offered to the deities. The guarantee of this right was a skewer they used at sacrificial banquets (a symbolon). The skewer, which was distributed by the (high) priest, gave the right to participate in the sacrificial banquet and to receive a certain share of meat. When the meat from the sacrifice became scarce and the guests were numerous, a substitute was created: the priest or sacred agent received a skewer that gave him the right to receive a piece of other meat, which was no longer sacred. The right to a portion of the sacrificed meat becomes the right to a portion of cereal or other food. The skewer is transmuted into the form of a stick, an obelos, a privilege given by the temple to its officials, which could be presented to other owners and merchants who gave the holder what he needed in food. The sticks were scratched and marked, ending up as a form of currency. According to Herodotus, it was a tyrant of the Lydians, Pheidon of Argos, who, due to the large number of obeloi (metal sticks) in circulation, collected them, removed them from the jurisdiction of the temple, melted them again and minted the first coins. Obelos turned into obulos. The first use of coins was to pay for the personal guard of the king, his mercenaries. In other words, money is born in the sacred sphere of the temple and then it was taken over and assumed by the political sphere, by the powerful and dominant individuals.

For Türcke, only much later, in a very different context, in the beginnings of Modernity, this need to atone or to pay for, became a systemic pressure, that is, a structural pressure, to produce surplus and profit. If worship was once the only and authentic place of payment (Zahlung), the modern economic system is a late derivative of an archaic sacred payment practice. The long historical process of its desecration (in the sense of making it profane, secular) needs to be taken into account if someone wants to understand what money is. In Classical Antiquity, money and currency were linked mainly to the need to pay wages of the soldiers, but soon afterwards, it became essential, due to the great economic activity surrounding the purchase and sale of slaves. At that time, the international slave trade pushed money (mainly in the form of coins) to allow its first major expansion phase. Yet, when the economy based on slavery suffered a crisis and collapsed with the invasion of the so-called barbaric peoples, the currency entered again in a secular phase of great lethargy.

Türcke claims that only in the Middle Ages, with the practice of donations to the Crusades and saints (Schenkungen and Stiftungen, donations and foundations of pious works), money will experience its second and definitive expansion in the Western Society. For him, the practice of making money donations to cathedrals, crusades, and saints pious works is at the origin of the current mone- 
tary system. Every Christian felt the need, the obligation to donate some of his possessions to the Church in order not to fall into eternal damnation (in hell). It was not the donation in itself that saved the sinner from eternal punishment, but the contrition of the heart with which the donation was to be made. However, without the donation, without the visible offering, the contrition did not seem true, did not seem real. Thus, the donations became increasingly public, sometimes bombastic. The offering, the donation, was made as a replacement for penance, that is, it could only erase the punishments of $\sin$, but not the sin itself. That is why donations were both indispensable and insufficient; they could not be lacking, but they did not replace the grace, the forgiveness of God.

According to Türcke, the need to make donations was at the beginning of the process of building Gothic cathedrals. Gradually, it was increasingly encouraged by the Popes and the Roman Curia. First, it was done by Boniface VII (1235 1303), who, preaching the crusade against the Moors to recover the sacred places, offered the nobles and kings who could not join in the crusade the possibility of achieving the same indulgence (the forgiveness of sins and the salvation from eternal damnation) through financial support and donation of goods and resources. Soon, the demand made by the Church to all Christians could be fulfilled or redeemed with the payment of large sums in currency. The donation replaced the personal sacrifice of going to Palestine for fighting, it was also the rescue of a debt, a guilt. Such desecration or substitution strategy was maximally reinforced when Popes Julius II (1503 - 1513) and Leo X (1513 - 1521) needed money to build the Basilica of St. Peter in Rome. They sent emissaries across Europe promising indulgences, that is, the atonement for guilt and sins and the risk of eternal damnation through the offering of gifts to St. Peter. As a result, coins, the use of which had been restricted and limited to very few situations, returned again to public and massive circulation in almost all Europe.

Türcke, diverging from Weber, considers that the Protestant Calvinist ethics only consolidated a system that was already structured in its fundamental bases. From then on, the use of money-first in the form of coins, then more and more in the form of a letter of credit, of shares and printed papers-began to work in a systemic way, that is, without the need for a social force to drive it or to justify it in the public sphere.

Money is only useful when you can have it anytime, anywhere. That is why, for centuries, coins were the champion form of money, due to its easy use, durability and transportability, even if limited. However, with the development of the international trade networks that have formed in Europe and around it since the $12^{\text {th }}$ century, some payments could no longer be made in coined currency. It was impossible to carry along with oneself huge amounts of coins. For this purpose, the foreign exchange system was invented, as a substitute for handling silver and gold coins during business trips. In the $17^{\text {th }}$ century major English traders also introduced tin and copper coins, called tokens, so that the poorest people, who never had access to gold and silver coins, could also buy goods. Yet currencies 
soon reached their limit and other forms of payment had to be invented, such as endorsing the exchange rate, bills of exchange, bank notes, letters of credit to the bearer, bank transfers, and several parallel forms of money. These new forms of payment and financing, which were born to facilitate financial transactions in specific situations, have themselves become forms of business and a source of financial income.

\section{Results}

We observed in this long historical path that there was a process of progressive dematerialization of money. Money started with the most precious material, the human body, went on in gold bars and paper banknotes form, and today it has become the most trivial and ephemeral thing, a simple electronic impulse on a computer screen. As an intermittent electronic impulse on any screen, money reached its physical limits of dematerialization and weightlessness, since it is now a mere little light that flickers unsteadily. Even so, and Türcke's arguments have demonstrated this very consistently, money has lost none of its meaning and function, nor of its immense power, and there is nothing announcing that, in whatever physical form it assumes, it will disappear. Money has survived all kinds of catastrophes, both environmental and social. Even when in wars, due to stagnation, the old barter economy returned, it just went back to an earlier stage, but never disappeared. In the argument exposed by Türcke, the temple became the central bank and the financial institution of the State. They watched the money, but they did not rule it, instead they served it.

According to Türcke's work, the one that first carried or attributed value and purchasing power to someone or something, was the sacred sphere, through the performance of sacrifices. So many millennia later, what remains fascinating about money is precisely its strange quality, attributed by humans, to summarize value, which is realized and updated through its purchasing power. The temple was the social instance that first instigated the quest for the potentially infinite accumulation of money, of value. In contemporary society, despite the fact that sometimes temples are empty and there is a crisis in priesthood, the magic and sorcery of assigning value and purchasing power continues with full strength, no matter what physical form money can assume or to whom value is attributed. For Türcke, money is a means of payment vested with the sacred that has been profaned, the result of a deception by the gods, which perhaps constitutes the very history of the process of humanization.

This rather instrumental evaluation of money functions or money "nature", ultimately as a necessary step in humanization history, would provoke an interesting and vigorous debate with the work of thinkers such as Walter Benjamin (1985), Franz Hinkelammert (2008), Assmann and Hinkelammert (1989) and with the capitalism critical tradition within Latin American Liberation Theology. The authors mentioned have also reflected on the sacredness of money, but rather linking it to idolatry and to the intrinsically sacrificial character of capitalist 
modern societies. For them, capitalism turned to be the (not one among others) idolatrous religion of everyday life, which hides its oppressing violence through the fascination and seduction it produces.

\section{Conclusion}

Whoever aspires for money always aspires for more than money: comfort, satisfaction, warmth, pleasure, power. For this reason, the monetary system cannot exist without an existential dome, without an imaginary dome, a superstructure of unfulfilled and insatiable fantasies and desires. Money is only the substitute, the possibility of access to the substitute. Yet, and this could be understood as one of Türcke's main conclusions, being satisfied with the substitute is better than nothing, and that is all the power and the key to the success of capitalism, the power to deceive substituting. However, taking the substitute for the thing itself is perverse, sick, and false. In the global system of financial capital and in the collective libidinal economy centered on commodities, the obsession with accumulation is increasingly guided by this perversion. However, money did not arise to be accumulated, wasted, to be invested profitably, or to be spent for pleasant and pleasurable purposes. Instead, according to Türcke, money came into the world to fulfill its function and to vanish, to become superfluous, to disappear. This was its original destination, although it was never fulfilled.

Looking ahead it becomes even more important, in the context of the manipulation of desires and the massive victimization of human beings in the capitalist globalized (dis)order, to realize the original mechanism of money and so to rebuild an economy on a non-sacrificial basis. To which extent most religious communities or religious movements are aware of, this challenge remains unpredictable. This review could be seen as an invitation to tackle the task.

\section{Acknowledgements}

This study is co-funded by Brazilian National Council for Scientific and Technological Development (CNPq).

\section{Conflicts of Interest}

The author declares no conflicts of interest regarding the publication of this paper.

\section{References}

Assmann, H., \& Hinkelammert, F. (1989). A idolatria do mercado: Um ensaio sobre economia e Teologia. Petrópolis: Vozes.

Baecker, D. (Ed.) (2009). Kapitalismus als Religion. Berlin: Kultur Verlag.

Benjamin, W. (1985). Kapitalismus als Religion. In R. Tiedemann, \& H. Schweppenhäuser (Eds.), Gesammelte Schriften (Vol. VI, pp. 100-103). Frankfurt: Suhrkamp.

Burkert, W. (1997). Homo Necans. Interpretationen Altgriechischer Opferriten und Mythen. Berlin: de Gruyter. https://doi.org/10.1515/9783110808476

Hinkelammert, F. (2008). Hacia una crítica de la razón mítica. México: Editorial Dríada. 
Löwy, M. (2006). Le capitalisme comme religion: Walter Benjamin et Max Weber. Raisons Politiques, 3, 203-219. https://doi.org/10.3917/rai.023.0203

Moreira, A. S. (2015). A religião sob o domínio da estética. HORIZONTE-Revista de Estudos de Teologia e Ciências da Religião, 13, 379-405. https://doi.org/10.5752/P.2175-5841.2015v13n37p379

Moreira, A. S. (2019). The Aestheticization of Religion in Brazil (and Probably Elsewhere). International Journal of Latin American Religions, 2, 125-141. https://doi.org/10.1007/s41603-018-0036-7

Simmel, G. (2008). Philosophische Kultur. Frankfurt: Zweitausendeins.

Türcke, C. (2003). Fundamentalismus_Maskierter Nihilismus. Springe: zu Klampen Verlag.

Türcke, C. (2008). Philosophie des Traums. Münich: C.H.Beck. https://doi.org/10.17104/9783406624933

Türcke, C. (2010). Sociedade excitada-Filosofia da sensação. Campinas: Unicamp Press.

Türcke, C. (2012). Hyperaktiv!: Kritik der Aufmerksamkeitsdefizitkultur (2nd ed.). Munich: C.H. Beck.

Türcke, C. (2015). Mehr! Philosophie des Geldes. Munich: C.H. Beck. https://doi.org/10.17104/9783406674587

Türcke, C. (2016). Lehrerdämmerung: Was die neue Lernkultur in den Schulen anrichtet. Munich: C.H. Beck. https://doi.org/10.17104/9783406688836

Türcke, C. (2019). Digitale Gefolgschaft: Auf dem Weg in eine neue Stammesgesellschaft. Munich: C.H. Beck. https://doi.org/10.17104/9783406731822 